\title{
Use of stable isotopes to investigate individual differences in diets and mercury exposures among common terns Sterna hirundo in breeding and wintering grounds
}

\author{
Ian C. T. Nisbet ${ }^{1, *}$, Joseph P. Montoya ${ }^{2, * *}$, Joanna Burger ${ }^{3}$, Jeremy J. Hatch ${ }^{4}$ \\ ${ }^{1}$ I.C.T. Nisbet \& Company, 150 Alder Lane, North Falmouth, Massachusetts 02556, USA \\ ${ }^{2}$ Department of Organismic and Evolutionary Biology, Harvard University, Cambridge, Massachusetts 02138, USA \\ ${ }^{3}$ Department of Biological Sciences, Rutgers University, Piscataway, New Jersey 08855, USA \\ ${ }^{4}$ Department of Biology, University of Massachusetts, Boston, Massachusetts 02125, USA
}

\begin{abstract}
We measured variations in stable isotope signatures $\left(\delta^{13} \mathrm{C}\right.$ and $\left.\delta^{15} \mathrm{~N}\right)$ and concentrations of mercury $(\mathrm{Hg})$ in breast feathers from pairs of common terns Sterna hirundo and their chicks at a breeding site in Buzzards Bay, northwestern Atlantic Ocean. By collecting 2 sets of feathers from the same adult birds, we compared values of $\delta^{13} \mathrm{C}, \delta^{15} \mathrm{~N}$ and $\mathrm{Hg}$ in feathers grown in the wintering area in the South Atlantic Ocean ('southern' feathers) and in the breeding area ('regrown' feathers). Regrown feathers had lower $\delta^{13} \mathrm{C}$, higher $\delta^{15} \mathrm{~N}$ and higher Hg than southern feathers. Values of $\delta^{13} \mathrm{C}$, $\delta^{15} \mathrm{~N}$ and $\mathrm{Hg}$ were much more variable in adults than chicks. Within families, $\delta^{13} \mathrm{C}$ and $\delta^{15} \mathrm{~N}$ were correlated between parents and chicks; Hg was correlated between male and female parents. Among regrown feathers, $\mathrm{Hg}$ was positively correlated with $\delta^{13} \mathrm{C}$ and negatively correlated with $\delta^{15} \mathrm{~N}$. These findings suggest that high individual exposure of common terns to $\mathrm{Hg}$ results from consumption of inshore prey at low trophic levels in restricted parts of Buzzards Bay and that members of pairs have similar diets in the breeding season but not in winter. They demonstrate the power of stable isotope analyses in revealing individual differences in foraging habits, diet and contaminant exposure in generalist predators.
\end{abstract}

KEY WORDS: Common tern $\cdot$ Diet $\cdot$ Feathers $\cdot$ Foraging $\cdot$ Mercury $\cdot$ Stable isotopes $\cdot$ Sterna hirundo Trophic web Resale or republication not permitted without written consent of the publisher

\section{INTRODUCTION}

Changes in proportions of stable isotopes of carbon and nitrogen have been used to elucidate trophic relationships within marine food webs (Dunton et al. 1989, Hobson \& Welch 1992, Rau et al. 1992, Hobson 1993, Hobson et al. 1994, Sydeman et al. 1997, Thompson et al. 1999) and to investigate the relationship of contaminant uptakes to trophic position within these webs

\footnotetext{
*E-mail: icnisbet@cape.com

** Present address: School of Biology, Georgia Institute of Technology, Atlanta, Georgia 30332, USA
}

(Cabana \& Rasmussen 1994, Jarman et al. 1996, 1997, Atwell et al. 1998, Bearhop et al. 2000b). Generally, nitrogen-15 $\left({ }^{15} \mathrm{~N}\right)$ is enriched at each successive level in a trophic web (Hobson et al. 1994, Michener \& Schell 1994), whereas carbon-13 $\left({ }^{13} \mathrm{C}\right)$ is enriched in inshore or benthic feeders relative to offshore or pelagic feeders. Stable isotopes have also been used to estimate the allocation of stored nutrient reserves to reproduction following the migration of seabirds from marine wintering areas to fresh-water breeding sites (Hobson et al. 1997, 2000) and seasonal or secular changes in diets (Thompson \& Furness 1995, Thompson et al. 1995). However, they have rarely been used to investigate inter- 
individual variation in diets or exposure to contaminants (Thompson et al. 1998, Bearhop et al. 1999, 2000b).

This paper reports a study of individual variation in diets and mercury ( $\mathrm{Hg}$ ) exposures among common terns Sterna hirundo. The common tern is a small inshore feeding seabird with a socially monogamous breeding system, biparental care, and generalized and opportunistic feeding habits (Nisbet 2002). The birds included in this study breed in Buzzards Bay, a shallow bay west of Cape Cod in the northeastern USA, and winter mainly on the coasts of eastern Brazil and northeastern Argentina (Hays et al. 1997). Common terns moult their body feathers in March-April, so that feathers taken from breeders soon after migration reflect dietary intakes in the winter quarters during that period, whereas feathers regrown in May-June reflect dietary intakes in the breeding area (Burger et al. 1992). We measured stable isotopes and Hg concentrations in regrown feathers to characterize and compare the trophic positions and $\mathrm{Hg}$ exposures of individual birds and mated pairs in the breeding area. We analyzed feathers from their chicks to compare the trophic positions and $\mathrm{Hg}$ exposures of parents and offspring. We also analyzed feathers grown by the same individuals in winter quarters to compare the trophic positions and $\mathrm{Hg}$ exposures of breeding and wintering birds.

Feathers provide a convenient and non-intrusive way to obtain repeated samples from the same individual birds. Although feathers are often used as markers of exposure to metals (Burger 1993, Furness 1993), they have not often been used for stable isotope studies of diet (but see Thompson et al. 1998, Bearhop et al. 2000b). In captive American crows Corvus brachyrhynchos, Hobson \& Clark (1992a) found that $\delta^{13} \mathrm{C}$ (the $\%$ difference in the proportions of ${ }^{13} \mathrm{C}$ between the sample and a standard reference material) in feathers reflected the dietary intake at the time of feather growth, diet-feather fractionation factors being +3.5 to $+4.4 \%$. In captive ring-billed gulls Larus delawarensis, Hobson \& Clark (1992b) found that diet-tissue fractionation factors were $+0.2 \%$ for $\delta^{13} \mathrm{C}$ and $+3.0 \%$ for $\delta^{15} \mathrm{~N}$ in feathers versus $+0.3 \%$ for $\delta^{13} \mathrm{C}$ and $+1.4 \%$ for $\delta^{15} \mathrm{~N}$ in muscle. In free-living great skuas Catharacta skua, Thompson et al. (1998) found that ${ }^{15} \mathrm{~N}$ was significantly higher in flight feathers than in body feathers, presumably because these were grown at different stages of the moult cycle. After growth, feathers are essentially inert structures with no further isotopic exchange with body constituents (Hobson \& Clark 1992a). Hence, we assume that breast feathers are an appropriate tissue for monitoring differences in diets at the times of feather growth, with an averaging time of a few days (Hobson \& Clark 1992a), whereas Hg in feathers reflects cumulative intake over a period of weeks to months (Furness et al. 1986, Bearhop et al. 2000a).
Based on previous studies of common terns in Buzzards Bay, we formulated several predictions and conjectures about individual variability in foraging habits, diet and $\mathrm{Hg}$ exposure in this species. Available data indicate that adults feed their chicks mainly on fish, whereas adults themselves feed on varied mixtures of fish, crustaceans, insects and other invertebrates (Nisbet 1973, 1983, 2002). Hence, we predicted that isotope patterns would show that the diets of adults are lower in the trophic web and more variable than those of chicks.

Birds breeding at our study site disperse widely to feed in varied habitats around Buzzards Bay; pairs often occupy exclusive feeding territories (Nisbet 1983), so that there is opportunity for considerable variation among birds and pairs in diets and contaminant exposures. Accordingly, we predicted that isotope patterns and $\mathrm{Hg}$ levels would be correlated between parents and chicks.

A previous study at the same site had shown that $\mathrm{Hg}$ levels in regrown feathers were much higher and somewhat more variable than those in feathers grown by the same birds in winter quarters (Burger et al. 1992). Because Hg levels are generally low in sediments in open parts of Buzzards Bay (Sears \& Battaglia 1990), we conjectured that the high levels and variability in contamination of terns might reflect enhanced formation of organomercury compounds in limited parts of the ecosystem, perhaps localized in some of the many eutrophied or low-oxygen inlets and harbors around the bay. Accordingly, we conjectured that $\mathrm{Hg}$ levels in regrown feathers might be correlated with consumption of inshore prey (high ${ }^{13} \mathrm{C}$ ). However, there is insufficient information about terns' diet in these places to formulate an a priori hypothesis about the relationship between $\mathrm{Hg}$ levels and trophic level (high or low ${ }^{15} \mathrm{~N}$ ).

Both members of common tern pairs feed in the same places during the egg laying and incubation periods (Nisbet 1983). Accordingly, we predicted that Hg levels and isotope patterns in feathers regrown during these periods would be correlated within pairs. However, during the egg laying period, males tend to eat the smaller items that they catch (including invertebrates) and to carry the larger items (mainly fish) to their mates (Taylor 1979, Nisbet 2001). Accordingly, we predicted that females would be higher in the trophic web (higher $\delta^{15} \mathrm{~N}$ ) than their mates.

We also investigated several questions for which we had no a priori hypotheses: (1) the relationship of $\mathrm{Hg}$ contamination to trophic level of prey, i.e. the correlation between $\mathrm{Hg}$ and $\delta^{15} \mathrm{~N}$ in regrown feathers; (2) how isotope patterns would differ between feathers grown in the winter quarters and regrown feathers; (3) whether males and females of mated pairs remain 
together in winter and/or have similar diets; (4) how isotope patterns in our coastal, temperate birds would differ from those in common terns breeding at a fresh-water, subarctic site (Hobson et al. 2000); and (5) whether isotope patterns or Hg levels would vary with parental age.

\section{MATERIALS AND METHODS}

Field work was conducted at Bird Island, Massachusetts, USA $\left(41^{\circ} 40^{\prime} \mathrm{N}, 70^{\circ} 43^{\prime} \mathrm{W}\right.$; Fig. 1) in May-June 1992. We selected 15 nests at the time of egg laying in mid-May, trapped both parents on each nest and pulled a small bunch of feathers (about 10) from the breast of each bird. We re-trapped 20 of the same birds at the time of hatching 20 to 23 d later and pulled the replacement feathers, which were readily identifiable because they were still in sheath (not fully regrown) and were white instead of gray (Basic instead of Alternate plumage: Nisbet 2002). We enclosed the study nests within low wire fences, ringed all chicks at hatching and checked them at intervals until they were almost ready to fly. We pulled breast feathers from all surviving chicks at age 20 to $23 \mathrm{~d}$. For pairs that raised 2 chicks to fledging, we use data from only the older chick. One chick that was adopted and fed by a pair other than its original parents is excluded from the study. Adults were sexed based on the presence or absence of a palpable egg in the oviduct at the time of egg laying, and/or by head length (Nisbet 2002). Our data set includes 8 (male + chick) pairs and 12 (female + chick) pairs (5 chicks were included in both). Fifteen adults had been banded when chicks and hence were of known age (5 to $17 \mathrm{yr}$ ). In 3 cases where both members of a pair were of known age, we used the mean age for comparison with data on chick feathers.

Feathers were stored at room temperature in paper envelopes until analyzed in 1998. At the Department of Earth and Planetary Sciences, Harvard University, samples were prepared by packing a small (ca. $0.5 \mathrm{mg}$ ) portion of the distal end of each feather into a tin capsule, which was then pelletized for flash combustion in an elemental analyzer. Stable isotope abundances were measured by continuous flow isotope ratio mass spectrometry using a Carlo-Erba NA1800 elemental analyzer interfaced to a VG Prism II mass spectrometer. All isotope abundances are expressed as $\delta^{15} \mathrm{~N}$ values relative to atmosphere or $\delta^{13} \mathrm{C}$ values relative to the PDB standard (Peedee Formation), using the definition:

$$
\begin{gathered}
\delta^{15} \mathrm{~N}=1000 \times\left({ }^{15} \mathrm{~N} /{ }^{14} \mathrm{~N}[\text { sample }]-\right. \\
\left.{ }^{15} \mathrm{~N} /{ }^{14} \mathrm{~N}[\text { standard }]\right) /\left({ }^{15} \mathrm{~N} /{ }^{14} \mathrm{~N}[\text { standard }]\right)
\end{gathered}
$$

This was also correspondingly used for $\delta^{13} \mathrm{C}$. The estimated precision of the isotopic analyses was $\pm 0.15 \%$ for $\delta^{15} \mathrm{~N}$ and $\pm 0.1 \%$ for $\delta^{13} \mathrm{C}$.
Fig. 1. Study site (Bird Island) in Buzzards Bay, Massachusetts, USA, between Cape Cod and the mainland. Note the complex configuration of the shoreline with many shallow inlets and harbors, some of which are eutrophied because of nitrogen input from urban or suburban developments

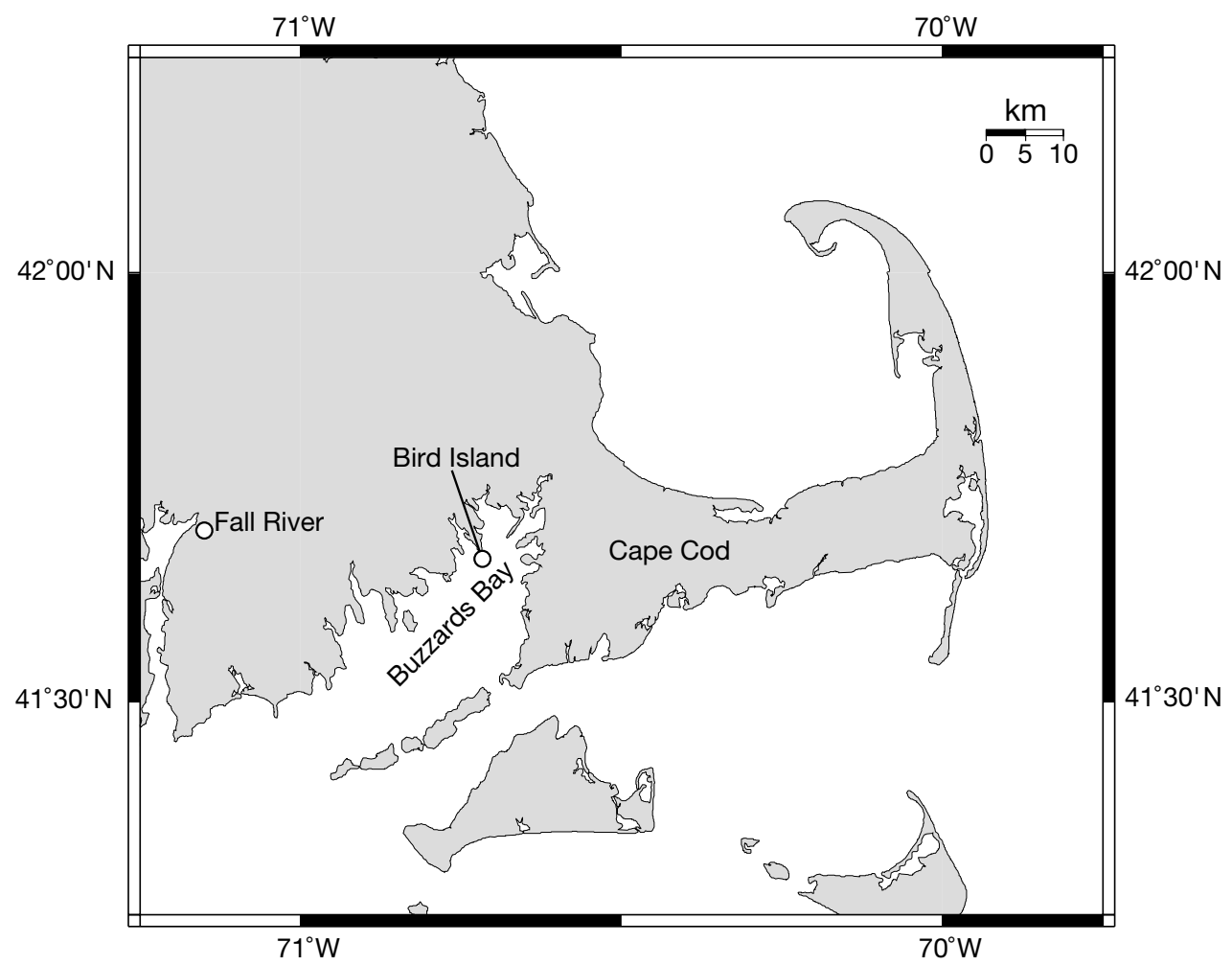



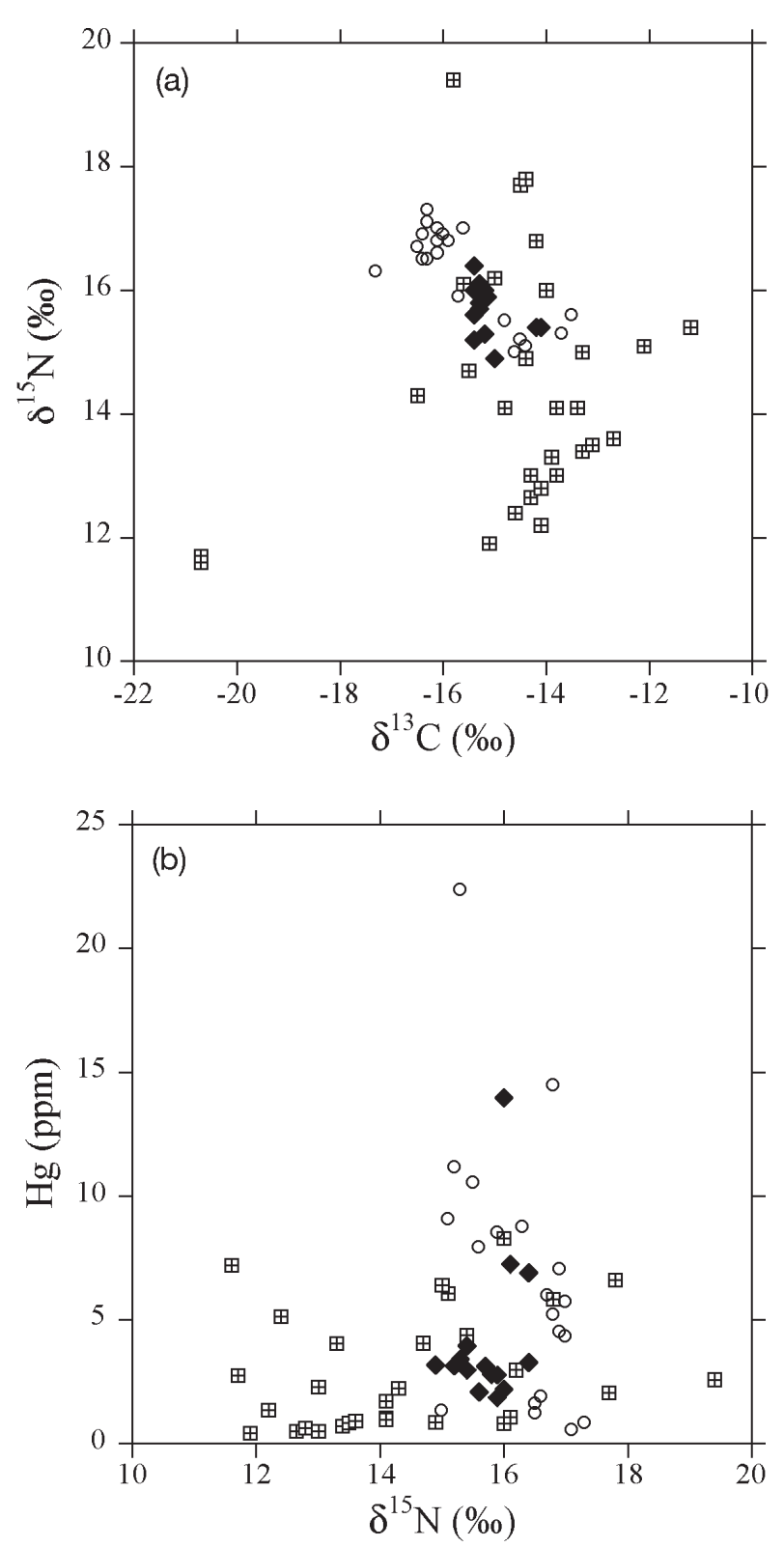

Fig. 2. Sterna hirundo. (a) $\delta^{15} \mathrm{~N}$ versus $\delta^{13} \mathrm{C}_{i}$ (b) $\mathrm{Hg}$ concentration versus $\delta^{15} \mathrm{~N}$. Adult feathers grown in the Southern Hemisphere $(\boxplus)$; adult feathers regrown at breeding ground (O); chick feathers grown at breeding ground $(\bullet)$
At the Environmental and Occupational Health Sciences Institute, Rutgers University, feathers were washed vigorously in deionized water alternated with acetone to remove loosely adherent external contamination (Burger 1993), and were air dried overnight. The sample was weighed to $0.1 \mathrm{mg}$. Feathers were then digested in $70 \%$ analytic grade $\mathrm{HNO}_{3}$ in a microwave vessel for 10 min under pressure of $9.16 \mathrm{~kg} \mathrm{~cm}^{-2}$; samples were subsequently diluted in deionized water. Hg was analyzed by the cold vapor technique (PerkinElmer AA). All concentrations in feathers are expressed in parts per million $\left(\mu \mathrm{g} \mathrm{g}^{-1}\right)$ dry weight. Instrument detection limits were $2 \times 10^{-4} \mu \mathrm{g} \mathrm{g}^{-1}$, but matrix detection limits were about an order of magnitude higher. All specimens were run in batches that included a standard calibration curve and spiked specimens as well as NIST (National Institute of Standards and Technology) standards. The accepted recoveries ranged from 85 to $105 \%$; no batches outside these limits were encountered in this study. The coefficient of variation on replicate samples ranged from 3 to $6 \%$. Quality control also included periodic blind analysis of an aliquot from a large sample of known concentration and blind runs of duplicate samples (Burger \& Gochfeld 1997).

Data were analyzed using STATISTICA ${ }^{\mathrm{TM}}$ software (StatSoft 2001). Differences between groups were analyzed using paired $t$-tests, Wilcoxon matched-pairs signed-ranks tests, Mann-Whitney $U$-tests or analysis of variance (ANOVA), with Tukey's tests to control for multiple comparisons. Variances were compared using F-tests, with the Bonferroni correction for multiple comparisons. Correlations among variables were analyzed using Pearson correlation coefficients or (for samples $\leq 10$ pairs) Spearman rank correlation coefficients. Spearman rank correlation coefficients were used to test the dependence of $\mathrm{Hg}$ levels or isotope proportions on parental age.

\section{RESULTS AND DISCUSSION}

Feathers grown by adults in the winter quarters are referred to as 'southern'; those regrown by adults in

Table 1. Sterna hirundo. Stable isotope signatures and mercury concentrations in common tern feathers from Bird Island, Massachusetts, USA. Southern: grown in southern hemisphere; Regrown: grown at breeding grounds; Chicks: chick feathers grown at breeding ground. Entries in the same column without a letter in common are significantly different. a,b: comparisons of means

(ANOVA with Tukey's tests, $\mathrm{p}<0.05)_{i} \mathrm{j}, \mathrm{k}$ : comparisons of variances $(F$-tests with Bonferroni correction, $\mathrm{p}<0.05$ )

\begin{tabular}{|lllll|}
\hline Feather sample & $\mathrm{n}$ & $\delta^{13} \mathrm{C} \pm \mathrm{SD}(\%)$ & $\delta^{15} \mathrm{~N} \pm \mathrm{SD}(\%)$ & $\mathrm{Hg} \pm \mathrm{SD}(\mathrm{ppm})$ \\
\hline Southern & 30 & $-14.6 \pm 2.0 \mathrm{a}, \mathrm{j}$ & $+14.4 \pm 1.9 \mathrm{a}, \mathrm{j}$ & $2.8 \pm 2.4 \mathrm{a}, \mathrm{j}$ \\
Regrown & 20 & $-15.6 \pm 1.0 \mathrm{a}, \mathrm{j}$ & $+16.3 \pm 0.8 \mathrm{~b}, \mathrm{k}$ & $6.7 \pm 5.4 \mathrm{~b}, \mathrm{k}$ \\
Chicks & 15 & $-15.1 \pm 0.4 \mathrm{a}, \mathrm{k}$ & $+15.7 \pm 0.4 \mathrm{a}, \mathrm{b}, \mathrm{k}$ & $4.2 \pm 3.1 \mathrm{a}, \mathrm{b}, \mathrm{j}, \mathrm{k}$ \\
\hline
\end{tabular}


the breeding area are referred to as 'regrown'. Values of both $\delta^{15} \mathrm{~N}$ and $\delta^{13} \mathrm{C}$ were more variable in feathers of adults, especially in southern feathers, than in feathers of chicks (Table 1, Fig. 2a). This is consistent with our prediction that the diets of adults would be more varied than those of chicks. However, mean values of $\delta^{15} \mathrm{~N}$ were not lower in regrown feathers than in chick feathers (Table 1, Fig. 2a). Thus, although parents are known to eat more invertebrates and smaller fish during the breeding season than those they feed to their chicks, the parents were not consistently lower in the trophic web, as predicted.

Values of $\delta^{13} \mathrm{C}$ and $\delta^{15} \mathrm{~N}$ in parents and chicks were significantly positively correlated; the correlations were higher for female parents than for males (Fig. 3a,b). This is consistent with our prediction that the diets of chicks would reflect the individual feeding locations and dietary specializations of their parents. However, $\mathrm{Hg}$ levels were not significantly correlated between parents and chicks, contrary to the corresponding prediction for $\mathrm{Hg}$. This suggests that the factors influencing exposure of chicks to Hg may differ from those influencing exposure of their parents. A previous study of seabirds also did not show significant correlation between $\mathrm{Hg}$ levels in feathers of parents and their chicks (Stewart et al. 1997), but that study used feathers of parents grown at sea during the non-breeding period.

$\mathrm{Hg}$ levels were higher and more variable in regrown feathers than in southern feathers (Table 1, Fig. 2b). This is consistent with the results of the earlier study at the same site (Burger et al. 1992), although the differences were somewhat less pronounced in this study. These results indicate that $\mathrm{Hg}$ levels are generally higher in the Buzzards Bay ecosystem than in the areas where our terns spend the winter (Burger et al. 1992). This might reflect either pollution from anthropogenic sources of $\mathrm{Hg}$ in the northeastern USA, locally enhanced methylation rates, or both.

Hg levels in regrown feathers were positively correlated with $\delta^{13} \mathrm{C}$ (Table 2). This is consistent with our conjecture that high exposures of adult terns to $\mathrm{Hg}$ in Buzzards Bay would be associated with feeding on inshore prey. Chick feathers, however, showed a negative (although nonsignificant) correlation between

Table 2. Sterna hirundo. Correlations among stable isotope ratios and mercury concentrations among adult common tern feathers regrown on breeding grounds. ${ }^{*} \mathrm{p}<0.05,{ }^{* *} \mathrm{p}<0.01$

\begin{tabular}{|llll|}
\hline Variable & $\delta^{13} \mathrm{C}$ & $\delta^{15} \mathrm{~N}$ & $\mathrm{Hg}$ \\
\hline$\delta^{13} \mathrm{C}$ & $+1.00^{\mathrm{a}}$ & $-0.79^{* *}$ & $+0.51^{*}$ \\
$\delta^{15} \mathrm{~N}$ & & +1.00 & $-0.47^{*}$ \\
$\mathrm{Hg}$ & & +1.00 \\
aPearson correlation coefficients $(\mathrm{n}=20)$ & \\
\hline
\end{tabular}
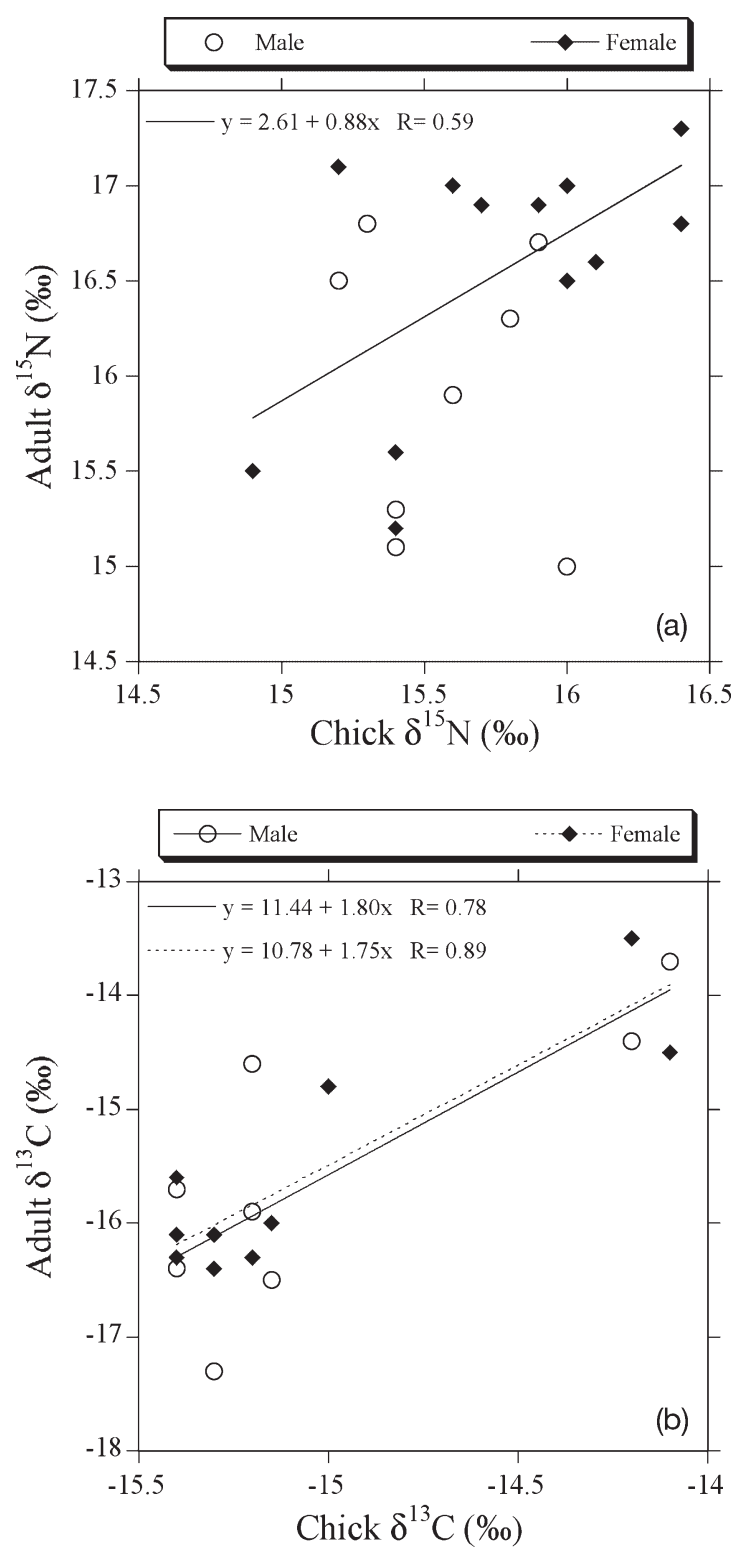

Fig. 3. Sterna hirundo. Relationships between: (a) ${ }^{15} \mathrm{~N}$, (b) $\delta^{13} \mathrm{C}$ from chick feathers, and regrown feathers of their parents. Adult male-chick pairs (O); adult female-chick pairs $(\diamond)$. Least-squares lines of regression are shown for significant relationships: solid line, male-chick pairs; dashed line, female-chick pairs

$\mathrm{Hg}$ and $\delta^{13} \mathrm{C}\left(\mathrm{r}_{\mathrm{S}}=-0.08, \mathrm{n}=15, \mathrm{p}=0.77\right)$. Hence, again, factors influencing exposure of chicks to $\mathrm{Hg}$ appear to be different from those operating in adults.

Within pairs, values of $\delta^{13} \mathrm{C}, \delta^{15} \mathrm{~N}$ and $\mathrm{Hg}$ in regrown feathers were all positively correlated between males and females (Fig. 4). The correlation for $\delta^{15} \mathrm{~N}$ was not statistically significant, but this may have been because of small sample size $(n=6)$. These findings are consistent with our predictions that diets of female 
common terns at the time of feather growth would reflect the individual feeding locations and dietary specializations of their mates.

Within pairs, males had significantly lower values of $\delta^{15} \mathrm{~N}$ in regrown feathers than females (range of male - female differences -1.5 to $+0.1 \%$, $n=15, \mathrm{p}<0.05$, Wilcoxon matched-pairs signed-ranks test). This indicates that females were higher in the trophic web
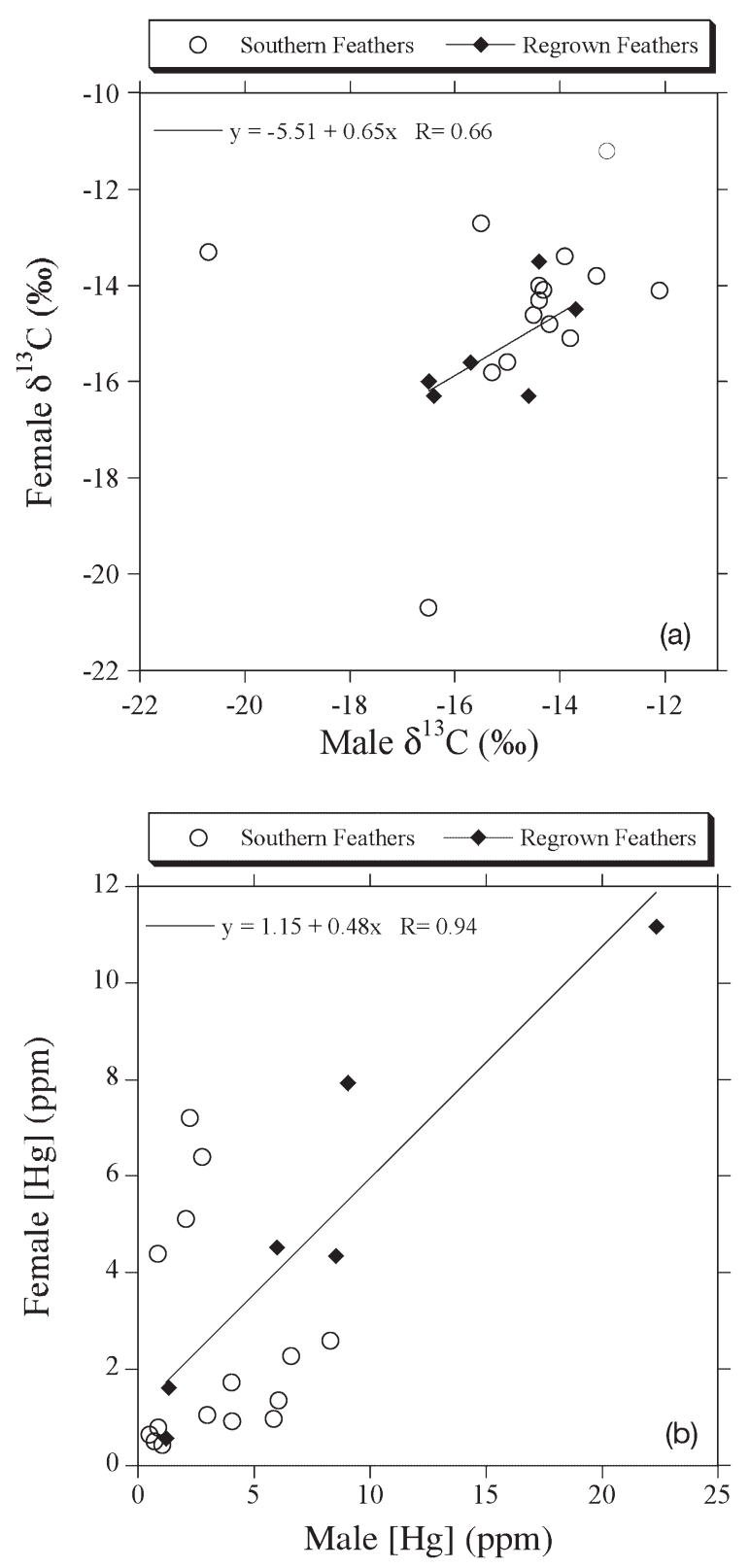

Fig. 4. Sterna hirundo. (a) $\delta^{13} \mathrm{C}$ and (b) $\mathrm{Hg}$ concentrations in southern and regrown adult feathers from mated pairs. Feathers grown in the southern hemisphere (o); regrown adult feathers $(\bullet)$. Least-squares lines of regression are shown for regrown feathers (correlations were not significant for southern feathers) than their mates, consistent with the observation that males eat smaller fish than those they bring to their mates. No other male-female differences were significant.

The following paragraphs refer to the 5 questions for which we had no a priori hypotheses. In regrown feathers, $\mathrm{Hg}$ was negatively correlated with $\delta^{15} \mathrm{~N}$ (Table 2), suggesting that the more contaminated prey consumed by common terns tend to be those at lower trophic levels. However, chick feathers showed the opposite (although nonsignificant) correlation ( $\mathrm{r}=$ $+0.11, \mathrm{n}=15, \mathrm{p}>0.05)$, again suggesting that factors influencing exposure of chicks to $\mathrm{Hg}$ appear to be different from those operating in adults. More information is needed to determine whether this is attributable to selective feeding of chicks on large or pelagic prey items or was caused by a seasonal shift in foraging by adults (chick feathers were grown 20 to 25 d later than regrown feathers). In great skuas, $\mathrm{Hg}$ levels in chick feathers were also positively correlated with $\delta^{15} \mathrm{~N}$, but in that study the variations were related to individual variation in the fraction of seabirds in the diet rather than to spatial variability in Hg contamination (Bearhop et al. 2000b). In an arctic marine food web, Hg levels were positively correlated with $\delta^{15} \mathrm{~N}$ across taxa (Atwell et al. 1998), but this also appeared to reflect trophic biomagnification rather than spatial variability in contamination.

Values of $\delta^{13} \mathrm{C}$ in southern and regrown feathers were not significantly different, but values of $\delta^{15} \mathrm{~N}$ were lower and much more variable in southern feathers (Table 1, Fig. 2a). These differences could have resulted from differences in background levels of $\delta^{15} \mathrm{~N}$, differences in diet or both. We have found no published information on $\delta^{15} \mathrm{~N}$ values in marine food webs in the areas of the southwest Atlantic Ocean where our birds moult, but $\delta^{15} \mathrm{~N}$ values in biota are spatially variable in the tropical South Atlantic off northern Brazil, where blooms of nitrogen-fixing cyanobacteria can introduce large quantities of isotopically depleted nitrogen into the food web (Carpenter et al. 1999). A published study of common terns in northeastern Argentina indicated that they fed on a wide variety of pelagic and inshore fish and terrestrial insects; insects were taken in the air, from the shoreline and from estuarine waters (Mauco et al. 2001). In the year when that study was conducted, insects were taken mainly in December, prior to the period when common terns moult, but if the birds in our study had consumed terrestrial prey in February-March, that could explain the low mean value and high variability in $\delta^{15} \mathrm{~N}$ in feathers grown at that time.

In southern feathers, there was no significant correlation between values of $\delta^{13} \mathrm{C}, \delta^{15} \mathrm{~N}$ or $\mathrm{Hg}$ of males and females within mated pairs (Fig. 4). This suggests that 
members of pairs have different diets in winter and probably winter in different areas.

Values of $\delta^{13} \mathrm{C}$ and $\delta^{15} \mathrm{~N}$ in muscle tissues of common terns breeding at Great Slave Lake, Northwest Territories, Canada, were $-21.8 \% \pm 0.5 \mathrm{SD}$ and $+9.2 \% \pm$ $0.3 \mathrm{SD}$, respectively, for the post-breeding adult sample (Hobson et al. 2000). These values are lower and much less variable than those in the feathers of our coastal common terns (Table 1), even after allowing for the small degree of fractionation in $\delta^{15} \mathrm{~N}$ expected between muscle and feathers (Hobson \& Clark 1992b). The different mean values presumably indicate that the inland birds had reached approximate equilibrium with fresh water prey, even though 1 sample was collected within 2 wk of arrival in spring. The low variability in all samples (comparable to that in our chicks) presumably reflects a more restricted diet in Great Slave Lake, although there is no direct information on terns' diet there.

Values of $\delta^{13} \mathrm{C}$ in chick feathers were negatively correlated with parental age, primarily because of high $\delta^{13} \mathrm{C}$ values in chicks of the youngest parents (Fig. 5). This suggests that the youngest parents tend to forage more inshore than older parents, perhaps because the former are less able to compete in foraging flocks over schooling fish (Safina et al. 1988). Hg levels tended to be higher in regrown feathers of younger adults, which is consistent with the same explanation.

In summary, our data provide an integrative measure of the feeding behavior of individual common terns. In contrast, most previous studies have focused on differences among groups rather than among individuals. Our comparison of feathers grown during the winter in the South Atlantic with those grown locally in Massachusetts during the breeding season revealed significant differences in foraging habitat (inshore vs offshore) but not average trophic position of adult terns. We found that mated pairs and their chicks showed a number of significant correlations and interesting relationships in their isotopic composition and $\mathrm{Hg}$ content. These patterns reflect subtle differences in the diet consumed by individual birds. Our results suggest that terns are exposed to $\mathrm{Hg}$ primarily through consumption of inshore prey in restricted areas of Buzzards Bay and that mated tern pairs have similar diets in their summer breeding habitat but not in their wintering grounds in the South Atlantic. Our data illustrate the value of the regrown feather technique for investigating individual and group differences in diets and contaminant exposures in migratory birds that moult in well-defined areas away from their breeding grounds. In addition, our results demonstrate the power of stable isotope analyses in revealing individual differences in foraging habits, diet and contaminant exposure in generalist predators.

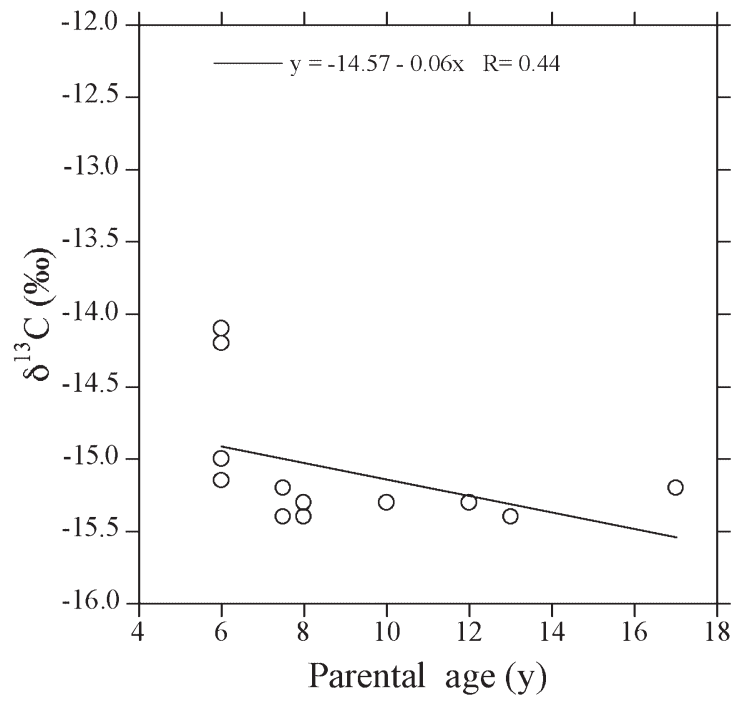

Fig. 5. Sterna hirundo. Relationship between $\delta^{13} \mathrm{C}$ in chick feathers and parental age. A least-squares line of regression is shown

Acknowledgements. Laboratory work was sponsored in part by NOAA National Sea Grant College Program Office, US Department of Commerce, under Grant No. NA46RG0470 to Woods Hole Oceanographic Institution. The views expressed herein are those of the authors and do not necessarily reflect the views of NOAA or any of its subagencies. Isotope analysis was further supported by Grants OCE9633510 and OCE9819086 to J.P.M. Hg analysis was further supported by NIEHS (ESO 5022) and the Environmental and Occupational Health Sciences Institute at Rutgers University. We thank Michael Stevens and April Mills for help in the field, Julia Tims for reviewing the manuscript and especially Michael Gochfeld for the original idea of collecting regrown feathers. We thank an anonymous reviewer for helpful comments on 2 earlier drafts.

\section{LITERATURE CITED}

Atwell L, Hobson KA, Welch HE (1998) Biomagnification and bioaccumulation of mercury in an arctic marine food web: insights from stable nitrogen isotope analysis. Can J Fish Aquat Sci 55:1114-1121

Bearhop S, Thompson DR, Waldron S, Russell JC, Alexander G, Furness RW (1999) Stable isotopes indicate extent of freshwater feeding by cormorants Phalacrocorax carbo shot at inland fisheries in England. J Appl Ecol 36:75-84

Bearhop S, Ruxton GD, Furness R (2000a) Dynamics of mercury in blood and feathers of great skuas. Environ Toxicol Chem 19:1638-1643

Bearhop S, Waldron S, Thompson D, Furness R (2000b) Bioamplification of mercury by great skua Catharacta skua chicks: the influence of trophic status as determined by stable isotope signatures of blood and feathers. Mar Pollut Bull 40:181-185

Burger J (1993) Metals in avian feathers: bioindicators of environmental pollution. Rev Environ Toxicol 5:203-311

Burger J, Gochfeld M (1997) Risk, mercury levels, and birds: relating adverse laboratory effects to field biomonitoring. Environ Res 75:160-175 
Burger J, Nisbet ICT, Gochfeld M (1992) Metal levels in regrown feathers: assessment of contamination in the same individuals on the wintering and breeding grounds. J Toxicol Environ Health 37:363-374

Cabana B, Rasmussen JB (1994) Modelling food-chain structure and contaminant bioaccumulation. Nature 372: $255-257$

Carpenter EJ, Montoya JP, Burns, J, Mulholland M, Subramaniam A, Capone, DG (1999) Extensive bloom of a $\mathrm{N}_{2}$-fixing symbiotic association (Hemiaulis hauckii and Richelia intracellularis) in the tropical Atlantic Ocean. Mar Ecol Prog Ser 185:273-283

Dunton KH, Shaupe SM, Golikov AN, Schell DM, Schonberg SV (1989) Trophic relationships and isotopic gradients among arctic and subarctic marine fauna. Mar Ecol Prog Ser 56:89-97

Furness RW (1993) Birds as monitors of pollutants. In: Furness RW, Greenwood JJD (eds) Birds as monitors of environmental change. Chapman \& Hall, London, p 86-143

Furness RW, Muirhead SJ, Woodburn M (1986) Using bird feathers to measure mercury in the environment: relationships between mercury content and moult. Mar Pollut Bull 17:27-30

Hays H, DiCostanzo J, Cormons G, Antas PdeTZ, Nascimento JLX, Nascimento Idel S, Bremer RE (1997) Recoveries of roseate and common terns in South America. J Field Ornithol 68:79-90

Hobson KA (1993) Trophic relationships among high Arctic seabirds: insights from tissue-dependent stable-isotope models. Mar Ecol Prog Ser 95:7-18

Hobson KA, Clark RG (1992a) Assessing avian diets using stable isotopes I: turnover of $\delta^{13} \mathrm{C}$ in tissues. Condor 94 : 181-188

Hobson KA, Clark RG (1992b) Assessing avian diets using stable isotopes II: factors influencing diet-tissue fractionation. Condor 94:189-197

Hobson KA, Welch HE (1992) Determination of trophic relationships within a high Arctic marine food web using $\delta^{13} \mathrm{C}$ and $\delta^{15} \mathrm{~N}$ analysis. Mar Ecol Prog Ser 84:9-19

Hobson KA, Piatt JF, Pitocchelli J (1994) Using stable isotopes to determine seabird trophic relationships. J Anim Ecol 63: 786-798

Hobson KA, Hughes KD, Ewins PJ (1997) Using stable-isotope analysis to identify endogenous and exogenous sources of nutrients in eggs of migratory birds: applications to Great Lakes contaminants research. Auk 114: 467-478

Hobson KA, Sirois J, Gloutney ML (2000) Tracing nutrient allocation to reproduction with stable isotopes: a preliminary investigation using colonial waterbirds of Great Slave Lake. Auk 117:760-774

Jarman WM, Hobson KA, Sydeman WJ, Bacon CE, McLaren EB (1996) Influence of trophic position and feeding location on contaminant levels in the Gulf of Farallones food web revealed by stable isotope analysis. Environ Sci Technol 30:654-660

Jarman WM, Sydeman WJ, Hobson KA, Bergqvist PA (1997)

Editorial responsibility: Otto Kinne (Editor),

Oldendorf/Luhe, Germany
Relationship of polychlorinated dibenzo-p-dioxin and polychlorinated dibenzofuran levels to stable-nitrogen isotope abundance in marine birds and mammals in coastal California. Environ Toxicol Chem 16:1010-1013

Mauco L, Favero M, Bó MS (2001) Food and feeding biology of the common tern during the nonbreeding season in Samborombon Bay, Buenos Aires, Argentina. Waterbirds 24:89-96

Michener RH, Schell DM (1994) Stable-isotope ratios as tracers in marine aquatic food webs. In: Lajtha K, Michener RH (eds) Stable-isotopes in ecology and environmental science. Blackwell Scientific Publishers, Oxford, p 138-157

Nisbet ICT (1973) Courtship-feeding, egg-size and breeding success in common terns. Nature 241:141-142

Nisbet ICT (1983) Territorial feeding by common terns. Colon Waterbirds 6:64-70

Nisbet ICT (2002) Common tern Sterna hirundo. In: Poole A, Gill F (eds) The birds of North America. The Birds of North America, Philadelphia, no. 618

Rau GH, Ainley DG, Bengtson JL, Torres JJ, Hopkins TL (1992) ${ }^{15} \mathrm{~N} /{ }^{14} \mathrm{~N}$ and ${ }^{13} \mathrm{C} /{ }^{12} \mathrm{C}$ in Weddell Sea birds, seals, and fish: implications for diet and trophic structure. Mar Ecol Prog Ser 84:1-8

Safina C, Burger J, Gochfeld M, Wagner RH (1988) Evidence for prey limitation of common and roseate tern reproduction. Condor 90:832-839

Sears JR, Battaglia J (1990) Use of benthic seaweeds to monitor heavy metals in Buzzards Bay, adjacent estuaries and New Bedford Harbor, Massachusetts. Southern Massachusetts University, Dartmouth, MA, Tech Rep 10-87

StatSoft (2001) STATISTICA ${ }^{\text {TM }}$ System Reference. StatSoft, Tulsa, OK

Stewart FM, Phillips RA, Catry P, Furness RW (1997) Influence of species, age and diet on mercury concentrations in Shetland seabirds. Mar Ecol Prog Ser 151:237-244

Sydeman WJ, Hobson KA, Pyle P, McLaren EB (1997) Trophic relationships among seabirds in central California: combined stable isotope and conventional dietary approach. Condor 99:327-336

Taylor IR (1979) Prey selection during courtship feeding in the common tern. Ornis Scand 10:142-144

Thompson DR, Furness RW (1995) Stable isotope ratios of carbon and nitrogen in feathers indicate seasonal dietary shifts in northern fulmars. Auk 112:493-498

Thompson DR, Furness RW, Lewis SA (1995) Diets and longterm changes in $\delta^{15} \mathrm{~N}$ and $\delta^{13} \mathrm{C}$ values in northern fulmars Fulmarus glacialis from two northeast Atlantic colonies. Mar Ecol Prog Ser 125:3-11

Thompson DR, Bearhop S, Speakman JR, Furness RW (1998) Feathers as a means of monitoring mercury in seabirds: insights from stable isotope analysis. Environ Pollut 101: 193-200

Thompson DR, Lilliendahl K, Solmundsson J, Furness RW, Waldron S, Phillips RA (1999) Trophic relationships among six species of Icelandic seabirds as determined through stable isotope analysis. Condor 101:898-903

Submitted: November 5, 2001; Accepted: June 6, 2002

Proofs received from author(s): August 9, 2002 